\title{
Chapter 3 \\ Diaspora Policies, Consular Services and Social Protection for Belgian Citizens Abroad
}

\author{
Jérémy Mandin
}

\subsection{Introduction}

The question of emigration and - more generally - of the situation of Belgian citizens living abroad occupies a specific place in the public space in Belgium. On the one hand, the figure of the Belgian emigrant, often described as an 'expat', is generally perceived positively and moving abroad is often depicted as a positive experience. This idea is reflected in many media productions, the most illustrative being maybe the weekly radio broadcast Belgians from the Other Side of the World (Les Belges du Bout du Monde) programed on the French-speaking Belgian public radio. On the other hand, beside this positive depiction of emigration, little media attention has been given to the lived reality of Belgian citizens abroad and even more limited salience to the policies targeting this specific population. At the same time, questions related to the social protection of citizens abroad seem to be a rather secondary topic in the Belgian political agenda, being largely absent of the everyday political debate. This chapter addresses the engagement of the Belgian state with its population abroad, with a special focus on policies targeting social protection issues.

The first part of the chapter will explore how the question of the Belgian population abroad has been institutionalized in Belgium. It will demonstrate how this institutionalisation is strongly linked to the process of federalisation that unfolded in Belgium, with each sub-national entity (or community) developing specific programs of international relations in various fields. Moreover, in response to the lack of public institutions dedicated to the support of the Belgian diaspora, Belgian citizens abroad have also organized themselves by creating associations that were

\footnotetext{
J. Mandin $(\bowtie)$

CEDEM, University of Liège, Liège, Belgium

IMMRC, KU Leuven, Leuven, Belgium

e-mail: jeremy.mandin@uliege.be
} 
historically built along ethnic lines of division between Flemish and Walloons. The second part of the chapter focuses on the policies of social protection that the Belgian state implemented in order to respond to the needs of its population abroad. It will describe the main characteristics of these policies. Beyond the provision of information and the signature of bilateral agreements that are two core components of the Belgian policy to support its citizens abroad, this part also addresses the Belgian Overseas Social Security (OSS) system that allows citizens living outside the European Economic Area (EEA) to access social security insurance schemes provided by the Belgian authorities. This specific program of social security was largely inherited from the Belgian colonial history and, in particular, from the problematics encountered by Belgian workers after the independence of Congo.

\subsection{Diaspora Characteristics and Home Country Engagement}

\subsubsection{Belgian Emigration as a 'Forgotten History'}

Emigration has been an important phenomenon in Belgium. During most of the nineteenth century and the beginning of the 20th, Belgium was a country of emigration. The number of people leaving the country exceeded the number of immigrants. During the second half of the nineteenth century, for example, many Belgians moved to Northern France to work in the textile and coal industries (Stengers 2004), fleeing difficult life conditions and scarce job opportunities at home. At the same period, more limited emigration movements were also oriented towards more distant destinations such as the United States (US), Brazil or Argentina (Stengers 2004), but also Canada (Jaenen 2011). Finally, during the Belgian colonial domination of Congo and despite the fact that the circulation between the metropole and the colony was strictly controlled by the Belgian colonial power, Belgians moved to this country (Stanard 2014). When compared with this rich history of emigration, it appears that the status of Belgium as an 'immigration country' (i.e. a country where immigration flows durably exceed emigration flows) is a rather recent development.

Emigration is still a significant phenomenon in Belgium. In July 2018, 471,401 Belgians were registered abroad, mainly in France $(132,557)$, the Netherlands $(38,824)$, Spain $(28,947)$, the United Kingdom $(28,293)$ and Germany $(28,008) .{ }^{1}$ According to the data of the Belgian General Directorate for Statistics, in the recent decades, the evolution of the emigration of Belgian citizens - while not linear seems to be characterized by a relative growth. With around 20,000 emigrants per

\footnotetext{
${ }^{1}$ Source: Direction Générale des Affaires Consulaires. These numbers are the numbers of Belgian citizens registered in the consular offices abroad. Registration with the consulates is highly recommended, but not mandatory. Thus, it is very likely that these figures underestimate the real numbers of Belgians living abroad.
} 
year during the 1980s and in the first half of the 1990s, the emigration of Belgian citizens reached a pick in 2008 with 47,868 people leaving the country. After a decrease in 2010 (partially explained by a new method of measuring emigrations) with 31,261 Belgians emigrating from Belgium, the outflows started to increase again during the 2010s. In 2017, the number of emigration was $37,557 .^{2}$

Despite this, most of the public and political attention in Belgium is focused on the immigration phenomena rather than emigration. In many ways, the history of Belgian emigration can be considered as a "forgotten history" (Morelli 1998). Regarding contemporary emigration phenomena, the question of outward migrations and the issue of the relation with the Belgian community abroad are rarely addressed, without being a top priority in the national political agenda.

\subsubsection{The Diaspora Infrastructure of Belgium}

At the federal level, the key institution in charge of the questions related to Belgians abroad is the Federal Public Service for Foreign Affairs, External Trade and Development Cooperation (Service Public Fédéral Affaires Etrangères, Commerce Extérieur et Coopération au Développement- SPF Foreign Affairs). Its missions include the "assistance to the Belgian living abroad and their protection". ${ }^{3}$ Within SPF Foreign Affairs, two services can intervene in the assistance of Belgians abroad. In case of crisis that potentially involves a large number of Belgian citizens, the Foreign Affairs Crisis Centre (Centre de Crise des Affaires Etrangères) is responsible. For individual cases, the responsible institution is the Directorate General for Consular Affairs (Direction Générale des Affaires Consulaires) which regroups a number of services divided between four directorates:

- The Directorate "Emergency assistance and judiciary affairs" regroups the services "Assistance to Belgians abroad", "International judiciary cooperation" and "European consular cooperation";

- The Directorate "Travel and Identity documents" regroups the services "Logistic and international norms", "Individual files and national regulation" and "Monitoring";

- The Directorate "People's rights" regroups the services "Nationality", "Family rights and civil status", "Notary", "Population and electoral affairs", "Regulation and document related anti-fraud measures";

- The Directorate "Visas" regroups the services "Regulation", "Individual files" and "Monitoring". 4

\footnotetext{
${ }^{2}$ Statbel (2018). Migrations internationales des Belges. https://statbel.fgov.be/fr/themes/population/migrations\#figures. Accessed 25 February 2019.

${ }^{3}$ Service Public Fédéral Affaires Etrangères, Commerce Extérieur et Coopération au développement, contrat d'administration 2016-2018. https://diplomatie.belgium.be/fr/sur_lorganisation/ mission_et_objectifs. Accessed 25 February 2019.

${ }^{4}$ See: https://diplomatie.belgium.be/fr/sur_lorganisation/organigramme_et_structure/c. Accessed 25 February 2019.
} 
Belgium has embassies and consulates in around 80 countries in the world. Its diplomatic missions abroad also include honorary consulates. Honorary consuls are generally recruited within the local population to provide Belgians abroad with a contact person in regions where consulates or embassies are not present. Honorary consuls are not required to have the Belgian citizenship and they do not always speak one of the official languages in Belgium. Their role may vary from one country to the other, depending of the context and of the needs of the main consulate. Honorary consuls have limited competences. For example, they cannot deliver emergency travel documents or visas. Their basic role includes providing support to Belgians in difficulty, collecting applications for ID cards and passports, communicating these applications to the consulate and issuing the documents at the end of the process.

The diaspora infrastructure of Belgium has also been affected by the process of federalisation that unfolded in the country. Because Belgium is a federal state, a number of competences have been transferred to different federal entities: three communities (the French community also known as the Wallonia-Brussels Federation, the Flemish community and the German-speaking community) and three regions (the Flemish region, the Wallonia region and Brussel-capital region). The communities, for example, are responsible for matters related to culture, education, youth policy or scientific research, among others. Regions are competent in matters related to the economy, employment, agriculture, housing, energy, transportation, environment, international trade, etc. An important element is that the different entities are also responsible for the international relations related to the aforementioned competences, which gives them a significant space for developing their own initiatives abroad. In this context, the different communities created institutions that are dedicated to the development of international relations. The Wallonia-Brussels Federation created the Wallonia-Brussels International (Wallonie-Bruxelles International, WBI), an institution in charge of the international relations of Wallonia and Brussels. Flanders has its own department for Foreign Affairs (Departement Buitenlandse Zaken). Both the Flemish community and the Wallonia-Brussels Federation developed their own network of delegations around the world. ${ }^{5}$ Even if the support of Belgians abroad is not the priority of such institutions, they often provide programs that include the promotion or the support of specific forms of emigration. For example, WBI provide incentives for people who want to move abroad in order to gain professional experience or to access specific education or training. Very often, this support aims at temporary forms of emigration and suppose the return of the emigrants in Belgium.

Broadly speaking, the two communities seem to engage in different ways with Belgian citizens abroad. Flanders seems more active than the Wallonia-Brussels Federation in securing socio-cultural links with its diaspora abroad. For example, the Flemish Government signed a bilateral convention with the Netherlands to facilitate the access of Flemish people to Dutch schools abroad. ${ }^{6}$

\footnotetext{
${ }^{5}$ See: http://www.federation-wallonie-bruxelles.be/index.php?id=90 and https://www.fdfa.be/en/ home. Accessed 25 February 2019.

${ }^{6}$ Convention of 30th of May 2016, also known as Ladies' Agreement (Damesakkoord), renewing a 1991 Convention known as Gentlemen's Agreement (Herenakkoord).
} 
Outside of the public institutions, the Belgian diaspora was also active in organizing itself in order to compensate for the lack of state-based support in different domains. Given the fact that - beyond the case of consular assistance - no governmental institution was created to engage with Belgians abroad, these two associations are crucial parts of the institutional framework through which non-resident Belgian citizens are represented in Belgium.

Historically, the Belgian diaspora has been organized along the ethnic lines of divisions that characterize the recent history of Belgium. In 1963, the association Belgians in the World (Belgïe in de Wereld, BIW) was created to defend the interests of Flemish abroad and to promote the Flemish culture worldwide. First, this association was open to French-speaking Belgian emigrants but rapidly, the latter were encouraged to found their own structure. In 1967, the association Belgium in the World (Belgique dans le monde, BDM) was created (Lafleur 2013). The two associations evolved and became the Flemish in Worlds (Vlamingen in de Wereld, VIW) for the Flemish part and Francophone Union of Belgians Abroad (Union Francophone des Belges à l'Etranger or UFBE) for the French speaking part.

These two associations are nowadays, the two main organisations that promote the interests of Belgians abroad. Progressively, the regional institutions started to support these two associations. VIW receives funding from the Flemish Ministry of External Relations, while UFBE is supported by Walloon authorities and the main political parties are represented in the board of directors (Lafleur 2013).

The two associations are characterized by different logics of action. UFBE's activity is mainly oriented towards providing information and counselling for Belgians abroad, in particular regarding their relations with the Belgian tax system, social security, pension system and health insurance. ${ }^{7}$ The association also publishes a newspaper that includes information regarding the political news of Belgium and the European Union (EU), as well as information regarding the life of Belgians abroad. The website of the association also provides the contacts of delegates in the different countries of destination. The delegates' function is to act as contact persons for Belgians abroad who need information. VIW also provides information to Belgians abroad on a range of topic including pensions, taxation and social security, as well as a network of contacts in destination countries. ${ }^{8}$ It also publishes a magazine. However, VIW also functions as a tool to promote the regional (in this case, Flemish) culture and identity abroad, a function that is much less present in the case of UFBE. Finally, both associations occasionally act as lobbies to demand political reforms in areas such as citizenship, voting rights or taxations on issues that concerns specifically the Belgian population abroad.

As mentioned above, questions related to emigration and the Belgian population abroad are not key topics in the Belgian political agenda. However, some political parties started to engage with these topics as illustrated in some occasions. First, during recent election campaigns, many parties included points of interest for

\footnotetext{
${ }^{7}$ https://www.ufbe.be/index.php/qui-sommes-nous. Accessed 25 February 2019.

${ }^{8}$ https://viw.be/nl/about-foundation-flemings-world. Accessed 25 February 2019.
} 
Belgians abroad in their electoral program. ${ }^{9}$ In these programs, Belgians living abroad were never labelled as "migrants" or "emigrants". In fact, the lexical field of "migration" was never used when it comes to label Belgian citizens living abroad. Other terms such as "Belgians of the world" or "Belgians abroad" were used instead. This illustrates the strict symbolic distinction that exists in the Belgium public sphere between Belgian emigrants and other migrant populations, such as immigrants from countries of the South. A second element is the creation, within some political parties, of specific organisations in charge of dealing with topics related to Belgians abroad. For example, the French-speaking right-wing Mouvement Réformateur (MR) created a Facebook page called MRI (For MR International) in which practical information and international news are posted for Belgians abroad. Another example is the Christian Democratic Centre (Centre Démocrate Chrétien, $\mathrm{CDH}$ ) which has its own International Space (Espace International) whose stated missions are to keep in touch with Belgian expatriates, defend their interests, inform them about matters that affect them directly or indirectly and keep a strong link with the life of the party. ${ }^{10}$

\subsubsection{Key Engagement Policies}

In Belgium, a Consular Code (Code Consulaire) was created by a law of 21st of December 2013 published in the Moniteur Belge on 21st of January 2014. The Consular Code regroups the principles that guide the missions of Belgian representations abroad, as well as the regulations related to the consular competences regarding civil registry, notary activities, nationality, etc. ${ }^{11}$ Until recently, however, the Code did not mention the services that Belgian representations had to provide. The law of 9 May 2018 added several articles to the Consular Code. Among these, Article 78 describes the situations in which Belgian representations abroad are competent to provide assistance. The types of services provided by consulates are listed in the Consular Code. Article 78 added by the 2018 law states that consular assistance is granted in case of: death of a Belgian citizen; serious accident happening to

\footnotetext{
${ }^{9}$ See, for example: the program of the Socialist Party (Parti Socialiste, PS) for the 2014 federal, regional and European Parliament elections (Plus forts ensemble. Pour un avenir plus juste. Programme 2014, élections européennes, fédérales et régionales); the 2014 program of Mouvement Reformateur (MR - centre right) (Programme général. Elections régionales, fédérales et européennes) ortheprogramoftheFlemishnationalistparty NVAin2014(Vooruitgang Verkiezingsprogramma Vlaamse, federale en Europese verkiezingen 25 mei 2014).

${ }^{10} \mathrm{See}$ : http://www.lecdh.be/le-parti/les-associations/lespace-international. Accessed 25 February 2019.

${ }^{11}$ For the different types of competences, see the law as published in the Moniteur Belge (pp.7 and sq.): http://www.ejustice.just.fgov.be/cgi_loi/loi_a.pl?=\&sql=(text+contains+(\%27\%27))\&rech= $1 \&$ language $=$ fr\&tri $=\mathrm{dd}+\mathrm{AS}+\mathrm{RANK} \&$ numero $=1 \&$ table_name $=1$ loi $\& \mathrm{~F}=\& \mathrm{cn}=2013122152 \&$ caller =image_a $1 \&$ fromtab=loi\&la=F\&pdf_page=7\&pdf_file=http://www.ejustice.just.fgov.be/ mopdf/2014/01/21_2.pdf. Accessed 25 February 2019.
} 
Belgian citizens; serious crimes from which Belgian citizens are victims; suspect disappearances of Belgian citizens; arrest or detention of a Belgian national; situations of extreme distress for Belgian citizens; major consular crisis or international child abduction when the child and/or one of the parents are Belgian. ${ }^{12}$

The general philosophy guiding the consular assistance is that Belgian citizens asking for assistance should first try to find their own solutions to their problems. Following this principle, the first objective of consular assistance is to help Belgians abroad to be able to solve their problems by themselves. Regarding repatriation, for instance, a consulate can help a person to contact a family member or a friend in order to pay for a flight ticket back home. If no solution is found, consulates can provide an exceptional assistance and organize the repatriation. In such exceptional case, the person requiring assistance is asked to sign an acknowledgement of debt. In other words, consular assistance is considered as a repayable advance payment.

An important addition made by the law of 2018 is that consular assistance will not be provided to the Belgians who also hold the nationality of the country where the assistance is required when the consent of the local authorities is required. ${ }^{13}$

Beyond these cases of consular assistance, a major mode of engagement of the federal institutions with Belgians abroad is the provision of information regarding international mobility (the term "emigration" is never used). The website of SPF Foreign Affairs provides rich information and advice for people who are preparing to travel abroad, either temporarily or on a more permanent basis. It also gives information about the possibility to benefit from social security and pensions from abroad. Many consulates and embassies also maintain a Facebook page in which they communicate useful information to Belgians living abroad, as well as international and Belgian news or information about cultural events.

Regarding political rights, Belgians abroad are allowed to vote in home elections. This right can be exercised for two typed of elections: the federal legislative elections and the European Parliament elections held in Belgium. The conditions are: being of Belgian nationality, being aged 18 or more and not be denied the right to vote. In order to vote, they also have to register in their consulate population registry. When Belgians abroad register in the consulate, they receive a form that they can complete if they want to be registered as voters. For those who are already registered in the consulate population registry, they can ask for the voter registration form to their consulate. The form is also available online. They also have to register as voters by completing a form distributed at the consulate or downloaded online. Belgians abroad are also attributed a "municipality of attachment" in Belgium. For several years, Belgians abroad where allowed to choose the municipality of their choice which would then automatically determine the constituency in which their vote will be accounted for. This possibility, however, was a source of concern for Flemish party fearing that French-speaking Belgians abroad would choose to

\footnotetext{
${ }^{12}$ Moniteur Belge, Code consulaire, http://www.ejustice.just.fgov.be/eli/loi/2013/12/21/ 2014A15009/justel

${ }^{13}$ See Code Consulaire, article 79.
} 
register in highly-disputed bilingual constituencies to increase the weight of Frenchspeaking voters (Lafleur 2008). The municipality of attachment is now determined as the last municipality of residence, or alternatively the city of birth, the city where the parents are registered, the city where the partner is or has been registered, the city where the parents up to the third degree is or has been registered, or, finally, the city of Brussels. Five voting modalities are offered to Belgians abroad: (1) in person in Belgium (in the city where the citizen is registered), (2) by proxy vote in Belgium, (3) in person at the consulate where the citizen is registered, (4) by proxy vote at the consulate, (5) by postal voting. Belgians abroad cannot stand as candidates for federal elections as one of the conditions for passive suffrage for these elections is for candidates to be registered in a Belgian municipality.

Belgians who are temporarily abroad during an election day can vote by proxy in national and sub-national elections. The impossibility to vote must be justified. A proof of absence or - if such a proof cannot be provided - a sworn statement has to be presented to the mayor of the municipality in which they reside in order to have the proxy vote authorized (Vintila et al. 2018, 7-8).

At the regional level, other policies have been developed regarding Belgians abroad. In the field of education, for example, the Flemish Government signed an agreement with the Netherlands allowing Flemish students to enrol in Dutch schools abroad (see above). Discussions about a similar agreement between the WalloniaBrussels Federation and France are currently taking place, but no agreement has been signed yet. ${ }^{14}$

\subsection{Diaspora Policies and Social Protection in Belgium}

A major element of Belgium's policy regarding the social protection of its diaspora is the provision of information to citizens living (or planning to live) abroad. The website of SPF Foreign Affairs provides basic information about how to access Belgium social protection abroad. The website specifically focuses on pensions ${ }^{15}$ and social security benefits, ${ }^{16}$ for which it provides concise information and links to relevant websites. An important element of this information policy is the creation, in 2010, of an online tool on the website of the Belgian Social Security agency. This internet-based tool allows Belgian citizens to check what are their rights in terms of social benefits abroad. Users are directed to a webpage entitled Leaving Belgium (Quitter la Belgique), where they are invited to provide information about their status: their nationality, the country of destination, their professional status, and the specific type of benefit they want information about. Once this information is

\footnotetext{
${ }^{14}$ Wallonie-Bruxelles International (2012). Rapport d'activité 2012.

${ }^{15} \mathrm{https}: / /$ diplomatie.belgium.be/fr/Services/services_a_letranger/pension. Accessed 25 February 2019.

${ }^{16}$ https://diplomatie.belgium.be/fr/Services/services_a_letranger/securite_sociale. Accessed 25 February 2019.
} 
uploaded, the website processes the data and provides the relevant information to the user. ${ }^{17}$

Beyond the provision of useful information to Belgian citizens abroad - and putting aside the EU regulations on social rights portability-, Belgium has also signed bilateral agreements addressing social security issues with several countries. In February 2019, 25 such agreements were in place. Some of them have been signed with the countries of origin of the largest immigrant workforce that Belgium recruited after World War II (Morocco, Turkey, Tunisia or Algeria, for example). Agreements have also been signed with Albania, Argentina, Australia, Bosnia, Brazil, Canada and Quebec, Chile, the Democratic Republic of Congo, South Korea, the United States, India, Israel, Japan, Kosovo, Macedonia, Moldavia, Montenegro, the Philippines, San Marino, Serbia and Uruguay. ${ }^{18}$ While variations exist from one agreement to another, they are usually based on the principle of reciprocity and allow that periods of work in both countries are taken into account in the determination of certain benefits, primarily, but not exclusively, in the area of pensions $^{19}$ (see below).

Consular intervention is yet another way the Belgian state provides a form of protection to its citizens abroad. This protection - as far as social protection is involved - however is mainly conceived as exceptional, at least in the cases where the need for protection does not concern a situation of crisis involving a large number of citizens. As already mentioned, Belgians abroad are first asked to solve their problem by themselves, if necessary, with a marginal support from the consular authorities (to contact relatives in the home country, for example). If the person in question is unable to organize his/her own solutions, consular authorities can provide further support, but the beneficiary needs to sign an acknowledgment of debt. Regarding the case of the repatriation of corpses, if the deceased person did not have an insurance organizing the repatriation and if her/his family members cannot or do not want to pay for such repatriation, then the Belgian state will organize the funeral in the country where the person is deceased. In other words, no body repatriation service is offered.

Finally, regarding the specific domains of pensions, healthcare, and family related-benefits, Belgium created a program specifically aiming to provide social protection for people working abroad: the Overseas Social Security (Sécurité sociale d'outre-mer, OSS). This program is the cornerstone of Belgium's social protection policies for citizens residing outside the EU. It is designed for Belgian citizens who work in countries without bilateral social security agreements with Belgium or where the social security system is deficient. Belgian citizens living within the EEA cannot enrol in this program. OSS takes its origins in Belgium's colonial history in Congo and Ruanda-Urundi. Indeed, starting in 1942, all the "non-indigenous"

\footnotetext{
${ }^{17}$ https://www.socialsecurity.be/CMS/fr/leaving_belgium/index.html. Accessed 25 February 2019.

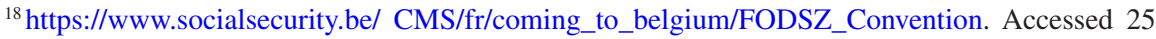
February 2019.

${ }^{19}$ See, for example, the agreement with Morocco: https://www.socialsecurity.be/CMS/fr/coming to_belgium/ convention/FODSZ_Convention_-Maroc. Accessed 25 February 2019.
} 
workers employed in the Belgian colony had to register to the colonial system of social protection..$^{20}$ In 1960, after Congo's independence, the Belgian state faced two problems: it had to insure the continuity of the social protection of colonial workers whose careers have been interrupted by the independence and, additionally, it also had to provide social protection to European workers still employed in the region who could not access a performant social protection regime locally. To address these issues, the Office for Overseas Social Security (Office de Sécurité Sociale d'Outre-Mer, OSSOM) was created by the law of 17 July 1963. Article 1 of this law stipulates that OSSOM brings together four institutions: the Fund for Pensions and Family Benefit of the Workers of Belgian Congo and Ruanda-Urundi; the Fund of Benefits for the Workers of the Belgian Congo and Ruanda-Urundi; the Special Fund for Benefits and the Fund for Disability of the Workers of Belgian Congo and Ruanda-Urundi. If the need to insure a form of continuity after the colonial system of social protection appears as the main argument for the creation of OSSOM, ${ }^{21}$ its field of application is not limited to the former colony anymore. The OSSOM social protection program was designed to provide forms of social protection to Belgian citizens living in countries with limited welfare infrastructures. Since its creation, OSSOM has been characterized by various reforms and is now named OSS. OSS is currently a service integrated within the Belgian National Office of Social Security (ONSS). Different dimensions of this social protection system will be discussed in the following paragraphs.

\subsubsection{Unemployment}

When it comes to protection against unemployment, the general rule is that one needs to reside in Belgium in order to access unemployment benefits offered by the Belgian state. In accordance with EU legislation, an exception is possible for those looking for a job in another EU Member State. In this case, and under certain conditions, the benefits can be received from abroad for 3 months (with possible extension). Next to the EU framework, Belgium does not offer financial protection against unemployment to its citizens abroad and the OSS scheme does not offer insurance against unemployment. Here again, information is the main form of support that Belgium provides to its emigrants, mainly through the website of the Belgian social security agency.

Some institutions, while not providing direct protection against unemployment, still provide some support regarding the job integration of (aspiring) emigrants. For

\footnotetext{
${ }^{20}$ OSSOM (2014). Rapport Annuel 2014. OSSOM.

${ }^{21} \mathrm{See}$, for example, the arguments developed in the Report produced by the Commission for Foreign Trade and Technical Assistance of the Belgian House of Representatives in May 1963: Chambre des Représentants (1963). Projet de Loi concernant la sécurité sociale d'outre-mer. Rapport fait au nom de la commission du commerce extérieur et de l'assistance Technique. 38e Législature. Document 431/7.
} 
example, at a regional level, the employment agencies of Wallonia (FOREM), Flanders (VDAB) and Brussels (ACTIRIS) regularly organize information sessions for Belgians who want to emigrate. Some of these sessions are focused on specific destinations and are often organized in collaboration with the authorities of the destination countries. The sessions typically provide information about foreign job markets, foreign job cultures and practical advices on how to find a job abroad.

\subsubsection{Health Care}

For Belgian citizens who move within the EEA, access to healthcare is regulated by EU legislation, while others can access the OSS program mentioned above. The program is separated from the general Belgian social security system. The OSS scheme covers different areas of social protection, including pensions, sickness, disability, maternity and medical insurance. The institution in charge of this scheme is ONSS. The user can choose the basic regime that covers a pension insurance, an insurance covering sickness, invalidity and maternity, and an insurance for medical care. The scheme also proposes complementary contracts covering work-related accidents and private accidents. ${ }^{22}$ The health insurance of the basic regime allows the person insured to receive a compensation when she/he is temporarily unable to work due to sickness, maternity leave or accidents. The insurance for medical care of the general scheme is a differed insurance (Assurance différée des soins de santé). It reimburses the medical expenses of the beneficiary who contributed to the scheme for at least 16 years. ${ }^{23}$ Belgians abroad can benefit from immediate reimbursement if they sign an additional healthcare contract (Contrats Soins de Santé). The additional insurance covers part of the costs (75\%) for medical care, hospital care, childbirth, physiotherapy (based on what is recognized by the Belgian legislation), orthodontic treatment, malaria (paludisme) treatment, vaccines, eyeglasses and ambulance transportation..$^{24}$ In September 2018, the monthly contribution for the basic regime was comprised between a minimum of 324.60 and a maximum of 1973.89 euros. The amount of the benefits depend on the contribution that the

\footnotetext{
${ }^{22} \mathrm{https} / / /$ www.international.socialsecurity.be/social_security_overseas/fr/assurances/regime-general/quest-ce-que-regime-general.html. Accessed 25 February 2019.

${ }^{23}$ Age conditions also apply depending of the number of years of contribution: 57 years old for 16 years of contribution, 56 years old for 18 years of contribution, 55 years old for 20 years of contribution, all the way to the minimum age: 50 years old for 30 years of contribution. See: https://www.international.socialsecurity.be/social_ security_overseas/fr/assurances/regime-general/assurance-differee-soin-de-sante.html. Accessed 25 February 2019.

${ }^{24}$ This concerns the case of medical care in the destination country: see: https://www.international. socialsecurity.be/social_security_overseas/fr/assurances/contrats-complementaires/contratssoins-de-sante.html. Accessed 25 February 2019.
} 
beneficiary chooses to pay (especially for pensions). The monthly contribution for the additional healthcare insurance contract was 146.78 euros. ${ }^{25}$

Next to OSS, SPF Foreign Affairs provides limited support in the area of healthcare. In case of accidents or serious illness, Belgian consulates can give advices about local doctors and hospitals with good standards as they usually keep a list of different specialist - among whom doctors - that Belgians abroad can contact in case of need. ${ }^{26}$

\subsubsection{Pensions}

As for healthcare, in the case of Belgian citizens who move within the EU, their right to access pensions and have these pensions paid abroad is mostly regulated by EU legislation. Belgians residing outside the EU can rely on the many bilateral agreements that Belgium signed and which allow that periods of activity in Belgium can be added to the period of activity in the country of destination for pension calculation. In addition to the general pension scheme, Belgians abroad have also access the OSS scheme described above. The basic regime of the OSS scheme includes a pension insurance working as a differed benefit insurance. In this sense, the OSS system is different from the Belgian pension system that is a repartition system (those who work pay for the elders). In the Belgian system, the amount of the pension benefits are based on criteria such as the person's past salaries and his/ her family situation. Overseas pension scheme is based on a system of capitalisation. The amount of the pension benefit depends on the contributions paid by the beneficiary, the age at which the contribution was paid, the duration of the participation to the insurance scheme and the age at which the pension started.

The website of SPF Foreign Affairs provides information on how to access pensions from abroad, mainly by providing the relevant web links.

The authority that Belgians abroad need to contact to receive a pension depend of the country of residence. If the country is an EEA country, Switzerland, or a country with which Belgium signed a bilateral agreement regarding social security, the competent authority is the authority of the country of residence. If the country is a country with which Belgium did not sign an agreement, Belgians abroad need to contact the Pensions Federal Service (Service Federal des Pensions) or the National Institute of Social Insurance for Independent Workers (Institut National d'Assurances Sociales pour Travailleurs Indépendants) in Belgium. Some bilateral agreements such as the one with Morocco - signed in February 2014 - stipulates that Belgian and Moroccan citizens who worked in Belgium and spend their pension in Morocco

\footnotetext{
${ }^{25} \mathrm{https}$ ///www.international.socialsecurity.be/social_security_overseas/fr/assurances/contratscomplemen taires/contrats-soins-de-sante.html. Accessed 25 February 2019.

${ }^{26}$ See, for example: Ambassade et Consulat de Belgique en Italie. 2018. Bienvenu en Italie! Guide pratique des formalités à accomplir pour qui s'établit en Italie. https://italy.diplomatie.belgium. be/fr/services-consulaires/guide-premiere-installation-en-italie-malte. Accessed 25 February 2019.
} 
have access to the Moroccan Health Insurance (AMO). The costs of the medical support is then reimbursed to AMO by the Belgian Health Insurance. ${ }^{27}$

To receive a Belgian pension, Belgians abroad need to provide a yearly life certificate (certificat de vie) signed by the consular authority and sent to the Belgian Pensions Federal Service. The person claiming a pension normally receives the template for the certificate every year, although the template is also available online. If the life certificate is not sent on time, the payment of the pension can be interrupted. Belgians who live in France, Germany or the Netherlands do not need to send the certificate. Indeed, an agreement on the electronic exchange of data between those countries has been concluded. This confirms that Belgium tends to put more emphasis on services offered in specific destination countries that concentrate the largest Belgian communities abroad.

\subsubsection{Family-Related Benefits}

The general principle to access family-related benefits (birth allowance and family allowance) is that parents need to be affiliated to the Belgian social security and to reside in Belgium. Exceptions are made, for example, when a person is a posted worker abroad (working abroad but still affiliated to the Belgian social security).

Some bilateral social security agreements that Belgium signed with non-EU countries include provisions on family benefits. ${ }^{28}$ These agreements usually facilitate the access to family benefits for workers working in one of the signatory countries. By way of example, the agreement with Morocco states that the period of activity in Belgium or Morocco are taken into account for opening family benefits rights in the other country and that Moroccan workers in Belgium who have children in Morocco can receive family benefits from Belgium and vice versa. ${ }^{29}$

In other words, these agreements do not really allow Belgians abroad to benefit from their home country family benefits, but insure that family benefits provided by the country where they work can benefit their children living in Belgium. Originally, this measure was mainly designed to benefit the Moroccan citizens living and working in Belgium, but with the development of forms of return migrations and new patterns of transnational North/South mobility, the reciprocity of the agreement also benefits Belgian citizens living in Morocco.

\footnotetext{
${ }^{27} \mathrm{https}$ ://www.socialsecurity.be/CMS/fr/coming_to_belgium/convention/FODSZ_Convention_Maroc. Accessed 25 February 2019.

${ }^{28}$ For the list of the agreements that include measure regarding family benefits, see: http://wallonie. famifed.be/ fr/familles/situation-de-lenfant/mon-enfant-r\%C3\%A9side-\%C3\%A01\%C3\%A9tranger. Accessed 25 February 2019.

${ }^{29}$ Convention générale sur la sécurité sociale entre le Royaume de Belgique et le Royaume du Maroc, published in Moniteur Belge on 25 June 1971. https://www.socialsecurity.be/CMS/fr/leaving_belgium/downloads/ff77f7f680185ec55456e6ec92c834a8. Accessed 25 February 2019.
} 
In addition to the provisions of bilateral agreements, the OSS scheme presented above provides an insurance covering sickness, invalidity and maternity. It includes a financial compensation for a maternity leave of 15 weeks, which is equivalent to the maternity leave provided in Belgium. However, the OSS program does not include the birth allowance that is granted in Belgium.

Lastly, consulates' role regarding family benefits seems to be limited to providing information through their websites.

\subsubsection{Economic Hardship}

One of the condition to access the guaranteed minimum income scheme (revenu d'intégration) in Belgium is to reside in the country. Therefore, Belgians abroad cannot apply for such resources.

Belgian consulates' websites sometimes provide information about the social security system of destination countries, including information about local institutions in charge of the host country's guaranteed minimum resource scheme. With regard to direct financial assistance of the consulate, as discussed above, only exceptional loans can be offered to Belgian nationals in case of economic hardship.

\subsection{Conclusions}

Emigration and diaspora-related policies are not at the top of the political agenda at the federal level in Belgium. Despite a rich history of emigration, Belgium is characterized by a lack of state-related structures dedicated - at the federal level - to defending the interests of the Belgian diaspora. Historically, this role has been performed by Belgians emigrants themselves, through the creation of two associations built according to the ethnic lines of distinction that characterizes the contemporary socio-political life in Belgium.

Following the federalisation process and the transfer of competences from the federal level to the different sub-national entities, the Belgian communities gained more and more space for developing their own initiatives in terms of international relations. Both the Flemish and the Walloon communities developed their own institutions in order to organize these initiatives. In the context of a global economy where cities and regions are competing with each other, citizens abroad are sometimes perceived as valuable assets and are increasingly seen as a way to enhance the "human capital" of the different communities. The engagement with diaspora, however, differs in terms of intensity and goals from one community to another. Flemish institutions, for example, seem more active in securing socio-cultural ties with their diaspora than the French-speaking institutions that seem more interested in securing business-related links. 
Regarding the specific field of social protection, the chapter examined the different ways in which Belgium intervenes in the area of welfare for its citizens abroad. As far as economic risks are concerned (unemployment, economic hardship), the engagement of Belgium toward its citizens abroad seems rather limited. The extension of the unemployment scheme to citizens abroad is very limited, no minimum income is accessible to them and consulates only provide financial assistance in exceptional circumstances if a commitment to reimburse is signed by the beneficiary. Regarding the other social protection areas addressed in this volume (healthcare, pensions, family-related benefits), a specificity of the Belgian policy toward its diaspora is the existence of a social security program dedicated to Belgians living outside of the EEA: the OSS. Interestingly, this program is largely inherited from the colonial history of Belgium and, in particular, from the specific circumstances encountered by many Belgian workers after Congo's independence.

Acknowledgements This chapter is part of the project "Migration and Transnational Social Protection in (Post)Crisis Europe (MiTSoPro)" that has received funding from the European Research Council (ERC) under the European Union's Horizon 2020 research and innovation programme (Grant agreement No. 680014). In addition to this chapter, readers can find a series of indicators comparing national social protection and diaspora policies across 40 countries on the following website: http://labos.ulg.ac.be/socialprotection/.

\section{References}

Jaenen, C. J. (2011). The implantation of Belgian immigrants in Western Canada. Canadian Ethnic Studies, 43(1/2), 237-251.

Lafleur, J.-M. (2008). Political Transnationalism and the State. Paris/Liège: IEP Paris and ULg. http://orbi.ulg.ac.be/handle/2268/143640. Accessed 10 July 2017.

Lafleur, J.-M. (2013). La participation politique transnationale des Belges expatriés: Un cas d'exportation des divisions ethniques ? Revue Européenne des Migrations Internationales, 29(2), 115-135.

Morelli, A. (Ed.). (1998). Les émigrants belges. Brussels: Editions Vie Ouvrière EVO.

OSSOM. (2014). Rapport Annuel 2014. OSSOM.

Statbel. (2018). Migrations internationales des Belges. https://statbel.fgov.be/fr/themes/population/migrations\#figures. Accessed 25 Feb 2019.

Stanard, M. G. (2014). Belgium, the Congo, and Imperial immobility: A singular empire and the historiography of the single analytic field. French Colonial History, 15(1), 87-109.

Stengers, J. (2004). Les mouvements migratoires en Belgique aux XIXe et XXe siècles. Revue Belge de Philologie et d'Histoire, 82, 311-348.

Vintila, D., Lafleur, J.-M., \& Nikolic, L. (2018). Report on political participation of mobile EU citizens: Belgium. San Domenico di Fiesole: European University Institute.

Wallonie-Bruxelles International. (2012). Rapport d'activité 2012. 
Open Access This chapter is licensed under the terms of the Creative Commons Attribution 4.0 International License (http://creativecommons.org/licenses/by/4.0/), which permits use, sharing, adaptation, distribution and reproduction in any medium or format, as long as you give appropriate credit to the original author(s) and the source, provide a link to the Creative Commons license and indicate if changes were made.

The images or other third party material in this chapter are included in the chapter's Creative Commons license, unless indicated otherwise in a credit line to the material. If material is not included in the chapter's Creative Commons license and your intended use is not permitted by statutory regulation or exceeds the permitted use, you will need to obtain permission directly from the copyright holder. 